\title{
INTERPRETASI HADIS: ANTARA \\ HERMENEUTIKA DAN SYARH AL-HADITS (STUDI KOMPARATIF)
}

\author{
Muhammad Syarifudin \\ Universitas Islam Negeri Sunan Ampel Surabaya \\ Email:02040620012@student.uinsby.ac.id

\section{Masruhan} \\ Universitas Islam Negeri Sunan Ampel Surabaya \\ Email: masruhan@uinsby.ac.id
}

\begin{abstract}
This article attempts to analyze the syarb al-hadith method of classical and contemporary scholars and the hermeneutic method of Islamic scholars in explaining (interpreting) the Prophet's hadith. Because most scholars who write about the interpretation of hadith with a hermeneutics approach, instead use references in classical hadith syarh. Therefore, the author wants to examine the relevance of hermeneutical methods or theories in the study of syarb al-hadith. Is hermeneutics appropriate to be applied as a single foundation in the interpretation of hadith or is it only a complement to the syarb al-badith? This article concludes after trying to compare the interpretations of the hadith commanding to fight humans until they say there is no god but Allah using the two approaches or methods above, and it turns out that both can go hand in hand and complement each other. Moreover, the hermeneutics approach is more about the meaning of the context of the hadith at the beginning of its emergence to the present, which requires an understanding of the meaning of the hadith according to its originator at the time of the background of the hadith (asbab wurud) and the history of this can be known through the syarah hadith method, especially, syarah hadith with other narrations or through the words of friends who lived contemporaries with the Prophet (originator). Besides that, the study of the original language of the text is also used as a reference in this case, which is part of the syarah of hadith as well.
\end{abstract}

Keywords: hermeneutics; interpretation; methodology; syarh al-hadith

\section{Abstrak}

Artikel ini mencoba menganalisis metode syarah hadis ulama klasik dan kontemporer dan metode hermeneutika cendekiawan Islam dalam 
menjelaskan (menginterpretasi) hadis Nabi. Karena, kebanyakan cendekiawan yang menulis mengenai interpretasi hadis dengan pendekatan hermeneutika, justru menggunakan rujukan dalam syarah hadis klasik. Oleh karena itu, penulis ingin meneliti relevansi metode atau teori hermeneutika dalam kajian syarh al-hadits. Apakah hermeneutika layak diterapkan sebagai pondasi tunggal dalam interpretasi hadis ataukah hanya menjadi pelengkap syarh al-hadits? Artikel ini mengambil kesimpulan setelah mencoba membandingkan penafsiran terhadap hadis perintah memerangi manusia sampai mereka mengucapkan tiada Tuhan selain Allah dengan menggunakan dua pendekatan atau metode di atas. Ternyata keduanya bisa berjalan beriringan dan saling melengkapi. Terlebih pendekatan hermeneutika lebih kepada pemaknaan konteks hadis di awal munculnya ke masa kini, yang mana hal itu memerlukan pemahaman akan makna hadis menurut pencetusnya di masa lahirnya hadis (asbab wurud) tersebut dan histori mengenai hal ini dapat diketahui melalui metode syarah hadis. Terutama syarah hadis dengan riwayat lainnya atau melalui perkataan Sahabat yang hidup sezaman dengan Nabi (pencetus). Di samping itu kajian bahasa asli teks juga dijadikan rujukan dalam hal ini, yang merupakan bagian dari syarah hadis juga.

Kata Kunci: hermeneutika; interpretasi; metodologi; syarh al-hadits

\section{Pendahuluan}

Hadis, salah satu sumber hukum Islam. Ia merupakan sabda Nabi Muhammad saw., salah satu pondasi dan asas ilmu-ilmu agama. Urgensi mempelajarinya tercermin dari salah satu fungsinya, menafsirkan al-Qur'an. Ia adalah ilmu warisan dari generasi awal umat Islam. Karenanya, pembahasan mengenai hadis akan selalu menjadi topik yang relevan setiap zaman. Walaupun ada sikap pesimistis dari sebagian orang yang mengatakan bahwa ilmu hadis di zaman sekarang tidak berkembang. Tetapi, itu tidaklah aktual.

Banyaknya kajian-kajian baru yang bermunculan dan ide-ide penelitian yang layak dipertimbangkan menunjukkan bahwa ilmu hadis terutama dirayabnya masih membuka lebar penelitian yang tanpa batas. Di antara kajian menarik yang dibahas oleh beberapa cendekiawan di masa sekarang adalah soal interpretasi (penafsiran). Mereka mengenalkan metode ataupun teori penafsiran yang bisa dikatakan nama baru di kalangan ulama Islam meskipun menurut 
beberapa cendekiawan praktiknya sudah ada sejak lama. ${ }^{1}$ Metode atau teori itu disebut dengan hermeneutika.

Hermeneutika dalam praktiknya oleh beberapa cendekiawan Islam terkadang menghasilkan produk yang dinilai menyelisihi ijmak ulama atau pun menyalahi kaidah yang sudah paten. Sehingga dalam perkembangannya, mayoritas ulama enggan untuk menggunakan pendekatan hermeneutika dalam interpretasi ayat maupun hadis dan lebih memilih mengikuti metode tafsir dan syarah klasik. Bahkan, tidak jarang ada yang menilai rendah kepada peneliti yang menggunakan pendekatan hermeneutika terlebih jika kesimpulan akhirnya tidak sesuai yang diharapkan. ${ }^{2}$

Hal ini menjadi salah satu sebab bertahannya metode syarah atau tafsir klasik. Di samping metodenya yang sudah matang, contoh produknya juga banyak. Berkebalikan dengan hermeneutika yang belum menghasilkan produk nyata dalam bentuk kitab, walau pun ada kajian per tema hadis tersebar dalam artikel-artikel maupun buku-buku tertentu. Misalnya, artikel Ahmad Fawaid berjudul "Reinterpretasi Hadis tentang Mabram (Pendekatan Hermeneutika)" berusaha menjelaskan hadis tentang syarat mahram wanita dalam berpergian dengan pendekatan hermeneutika Fazlur Rahman (double movement) dengan melakukan kritik sanad dan matan serta i'tibar terlebih dahulu. Adapun kesimpulan yang didapat bahwa syarat mahram itu bersifat temporal sesuai standar keamanan. Sehingga jika sudah ada aturan-aturan hukum, perundang-undangan dan kebijakan-kebijakan publik yang dapat menjamin perlindungan terhadap wanita maka mahram (person)

1 M F I Dr. Edi Susanto, Studi Hermeneutika Kajian Pengantar (Jakarta: Kencana, 2016), 16.

2 Dr. Edi Susanto, 34-42. Edi menyebutkan bahwa Sikap ulama dan cendekiawan berkaitan dengan hermeneutika bisa dibagi menjadi tiga kelompok. Kelompok yang menolak keras, kelompok yang menerima mentah-mentah dan kelompok yang moderat (pertengahan). 
tidak diperlukan lagi, namun mahram bisa relevan lagi jika situasinya sama dengan kondisi saat hadis muncul. ${ }^{3}$

Sebelumnya, Imam Ibnu Hajar dalam artikelnya yang berjudul "Reinterpretasi Hukum Larangan Bepergian tanpa Mabram bagi Perempuan" meskipun tidak secara tegas menggunakan pendekatan hermeneutika dalam kajian interpretasinya namun dalam sub pembahasan "Memaknai Hadis Bepergian bagi Perempuan; Interpretasi Baru”, tampak bahwa Imam Ibnu Hajar menggunakannya. Terlihat dalam mengkompromikan hadis larangan bepergian bagi wanita tanpa mahram dan hadis yang menunjukkan kebolehannya dengan kesimpulan yang mengarah atas adanya 'illah (alasan) sehingga jika 'illah ini tidak ada maka wanita boleh saja bepergian tanpa mahram. ${ }^{4}$

Dalam pengamatan penulis, dua kajian di atas sudah bagus, meskipun kesimpulan bahwa mahram bisa diganti dengan aturan keamanan kurang tepat, karena hal semacam itu sudah ada sejak dahulu, namun masih saja menimbulkan tindak kejahatan terhadap wanita bahkan di zaman modern sekalipun. Sehingga mahram (person) masih dibutuhkan, sebagaimana yang menjadi kesimpulan Imam Ibnu Hajar. Namun, hal yang perlu digarisbawahi adalah kesesuaian hasil antara syarh al-hadits dari ulama dan hermeneutika yang menunjukkan sebenarnya keduanya bisa saling melengkapi.

Artikel lainnya ditulis oleh Ihsan Siregar dan M. Nasrun Siregar "Reinterpretasi Hadis Mayat Diazab atas Tangisan Keluarganya dengan Hermeneutika Paul Ricoeur". Inti dari artikel ini bahwa interpretasi dengan pendekatan hermeneutika Ricoeur bisa dibagi menjadi tiga bagian. Pertama, proses menafsirkan teks berawal dengan menebak makna kata dalam teks dengan megkaji struktur

3 Ahmad Fawaid, "Reinterpretasi Hadis Tentang Mahram (Pendekatan Hermeneutika)," Nur El-Islam 3, no. 1 (2016): 194, https://ejurnal.iaiyasnibungo.ac.id/index.php/nurelislam/article/view/38.

${ }^{4}$ Imam Ibnu Hajar, "Reinterpretasi Hukum Larangan Bepergian Tanpa Mahram Bagi Perempuan.Pdf," Al-Manabij: Jurnal Kajian Hukum Islam 6, no. 1 (2012): 152-53, https://doi.org/https://doi.org/10.24090/mnh.v6il.594. 
bahasa dan diksi kata hadis sehingga didapat bahwa tangisan yang dimaksud adalah tangisan yang meratapi sebagaimana disebutkan dalam hadis Umar dan anaknya.

Kedua, proses pencarian penjelasan kritis dan metodis terkait makna awal atau dengan kata lain asbab wurud hadis. Terdapat riwayat Aisyah yang menjelaskan sebab hadis itu. Menurutnya, hadis itu ditujukan kepada orang-orang Yahudi yang menangisi mayit. Ketiga, proses dialog antara pembaca dan teks. Sehingga diperoleh kesimpulan bahwa hadis tentang mayat yang disiksa karena tangisan keluarganya memberikan pemahaman akan sikap sewajarnya dari abl al-musibah. ${ }^{5}$ Hal yang menarik dari ini adalah rujukan yang digunakan dalam melakukan proses hermeneutika Ricoeur yang masih kembali pada perkataan Sahabat yang merupakan rujukan dalan syarh al-badits. Sebenarnya ada beberapa artikel yang membahas interpretasi tema hadis dengan pendekatan hermeneutika tapi penulis hanya menyebutkan tiga artikel di atas sebagai petunjuk akan adanya contoh lain.

Dari berbagai literatur review di atas dapat dilihat bahwa kajian interpretasi hadis dengan pendekatan hermeneutika yang dilakukan oleh para pengkaji di atas masih merujuk kepada syarah al-hadits yang menunjukkan akan kebutuhan hermeneutika. Berdasarkan itu, penulis ingin meneliti relevansi metode atau pun teori hermeneutika dalam kajian syarb al-badits. Apakah hermeneutika layak diterapkan sebagai pondasi tunggal dalam interpretasi (tafsir) hadis ataukah hanya menjadi pelengkap syarh al-hadits metode ulama Islam, atau bahkan tidak diperlukan dalam syarh al-hadits?

Penelitian ini adalah penelitian kualitatif dengan pendekatan tinjauan pustaka. Sehingga fokus menghimpun sumber yang membahas mengenai hermeneutika hadis dan contoh yang diberikan kemudian peneliti bandingkan contoh tersebut dengan

5 Ihsan Siregar, M Nasrun, "REINTERPRETASI HADIS MAYAT DIAZAB ATAS TANGISAN KELUARGANYA,” Ulul Albab 19, no. 1 (2018): 150-257, https://doi.org/10.18860/ua.v19i1.4837. 
syarah dari ulama terkenal. Sehingga didapat hasil perbandigan yang diharapkan bisa menjawab rumusan masalah yang peneliti tanyakan.

Untuk mencapai tujuan tersebut maka peneliti menggunakan kualitatif-analitis komperatif, dengan menganalisis isi dari gagasan dan contoh yang disajikan dalam beberapa buku dan artikel kemudian dilakukan studi komparasi antara interpretasi hadis dengan syarah hadis dan metode hermenutika.

Namun sebelum itu peneliti merasa perlu untuk membahas mengenai syarh al-hadits di kalangan ulama klasik hingga kontemporer terlebih dahulu, mengingat bahwa kajian ini membahas perbandingan syarah hadis dan hermeneutika dalam menginterpretasikan hadis sehingga sangat diperlukan pendahuluan mengenai keduannya meskipun secara ringkas agar mempermudah dalam memahami persamaan dan perbedaan antar keduanya.

\section{Pembahasan}

\section{Syarh al-Hadits}

Syarh al-hadits (شرح الحديث) merupakan kata majemuk yang terdiri dari mudhaf dan mudhaf ilahi, ada dua kata yang menyusunnya

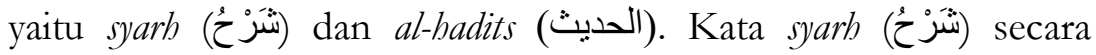
bahasa berasal dari bahasa Arab شَحَح - يشرَح ( berarti الْكَنْْف (al-kasfu; menyingkap atau menafsirkan). ${ }^{6}$ Adapun

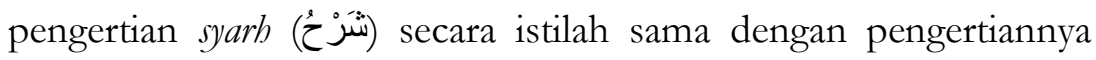
secara bahasa.

Namun, syarb yang dimaksud oleh ulama hadis adalah syarah yang mencakup matan dan sanad. Kata al-hadis (الحديث) secara bahasa berasal dari kata bahasa Arab حدَث - يحدُث (badatsa-yahdutsu)

6 Muhammad Abi Bakr ar-Razi, Mukhtar As-Sihah (Beirut: ad Dar an Namudzajiyyah, 1999), 163. 
yang berarti الْخَبَر (khabar, berita), نقيضن الْقََيمِ (naqidh al-qadim; lawan dari lama; baru $)^{8}$ dan makna yang lainnya.

Adapun pengertian al-hadits (الحديث) secara istilah adalah:

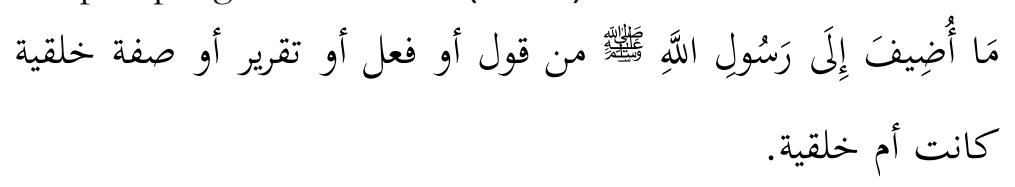

"Segala sesuatu yang disandarkan kepada Rasulullah saw. baik itu perkataan, perbuatan, persetujuan atau sifat fisik maupun perilaku."9

Namun, jika direnungkan dengan seksama, para ulama generasi pertama menjadikan perkataan Sahabat dan Tabi'in masuk ke dalam pengertian hadis. Dan tentu saja ini sebelum istilah hadis paten. Begitu juga perkataan mereka mengindikasikan bahwa yang dimaksud dengan hadis itu mencangkup sanad juga, bukan hanya matan. Terlebih matan dan sanad merupakan fokus utama (maudhu') yang dibahas dalam ilmu hadis.

Lalu pengertian syarh al-hadits (شرح الحديث) sebagai suatu cabang ilmu ada beberapa ulama yang mendefinisikannya. Syekh Muhammad Umar Bazmul berkata,

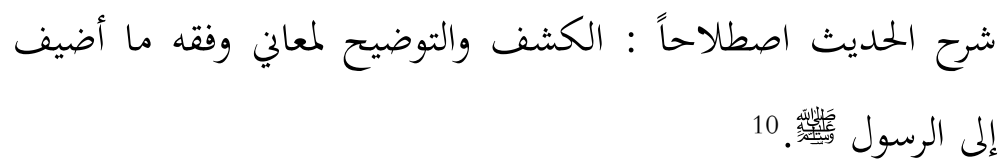

"Pengertian syarh al-hadits secara istilah adalah penjelasan makna-makna (kata maupun kalimat) dan pemahaman yang

7 Muhammad Ya'kub al Fairuzabadi, Al-Qamus Al-Mubith (Beirut: Muassasah ar-Risala, 2005), vol. 167.

8 Muhammad Mukrim Ali Ibn Manzhur, Lisan Al-'Arab (Beirut: dar alShodir, 1414), vol. 2/131.

${ }^{9}$ Muhammad Abdurrahman as-Sakhowi, Fath Al-Mughith Bi Syarh Alfiyah Al-Hadith (Mesir: Maktabah as Sunnah, 2003), vol. 1/22.

10 Muhammad Umar Salim Bazmul, Al-Mathali' Wa Al-Ushul Fiy Fahmi Abadith Ar-Rasul (Jaza'ir: Dar al-Mirath an-Nabawiy, 2017), vol. 1/588. 
terkandung pada segala sesuatu yang disandarkan kepada Rasulullah saw. (baca: hadis).”

Syarh al-hadits atau fiqh al-hadits sebagai metode interpretasi dalam memahami hadis sangat penting perannya, terutama bagi ahli hadis. Karena kekurangan dalam hal ini bisa mengakibatkan salah dalam memahami maksud yang dikandung dari hadis. Sehingga perhatian ulama dalam menyusun kitab-kitab syarb alhadits menyamai perhatian mereka terhadap ilmu rijal al-badits bahkan itulah kenyataannya sebagaimana perkataan Ibnu Hajar,

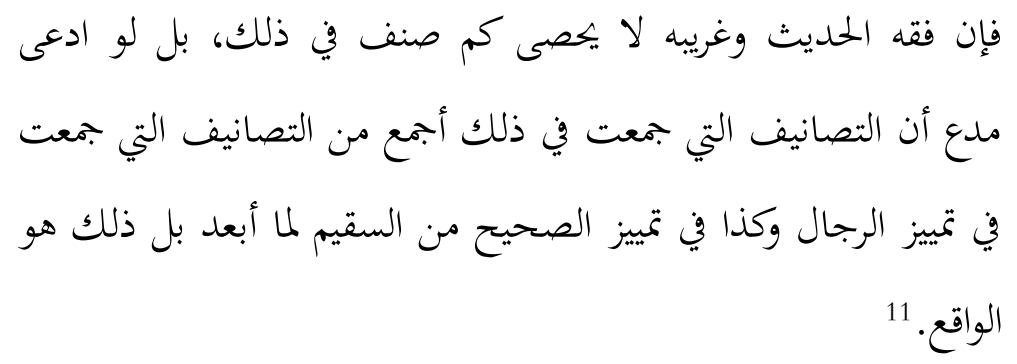

Namun, hal ini tidaklah berarti bahwa perkara mengetahui hadis sahih dan hadis lemah tidaklah penting, bahkan itulah jalan menuju figh al-hadits. Sehingga maksud dari pernyataan di atas menunjukkan bahwa perhatian terhadap fiqh al-hadits dan makna yang terkandung di dalamnya termasuk tujuan asas yang harus diusahakan oleh orang berilmu agar mencapai kebahagiaan di dunia dan akhirat.

Urgensinya hal ini dimungkinkan dalam beberapa hal, di antaranya, bahwa istidlal (pendalilan) yang benar itu bergantung pada dua hal penting. Pertama, keotentikan dalil. Kedua, benarnya cara istidlal yang meliputi pemahaman yang bagus, tidak adanya penentang (mu'aridh), dan tidak adanya hukum penghapus (naskb). Adapun yang pertama merupakan fokus dari ilmu hadis (mushthalah al-hadits).

11 Ahmad Ali Muhammad Ibnu Hajar, An-Nukat 'ala Kitab Ibn as-Salah (Madinah: 'Imdah al-Bahth al-'ilmi bial-Jamiah al-Islamiyah, 1984), 1/230.

380 | TAJDID vol. 20, No. 2, Juli - Desember 2021 
Metode syarh al-hadits yang dipakai oleh ulama di dalam kitab mereka tidak keluar dari hal ini. Pertama, syarh hadis dengan hadis, karena apa yang mujmal atau diringkas dalam suatu hadis, dijelaskan di riwayat lain dari hadis yang sama. Atau menjelaskan hadis dengan hadis yang lainnya di permasalahan yang sama. Inilah metode yang paling utama dan paling selamat dari kesalahan. ${ }^{12}$

Imam Ahmad bin Muhammad bin Hanbal (w. $240 \mathrm{H}$ ) mengatakan sebagaimana dikutip oleh Bazmul bahwa hadis itu jika belum terkumpul jalur-jalur periwayatannya, kamu tidak bisa memahaminya. Karena hadis itu saling menafsirkan. Hal senada juga disampaikan oleh Qadhi 'Tyadh, "Hadis itu saling menafsirkan, saling menerangkan yang janggal atau masalah dari riwayat yang mujmal maupun yang mutasyabih."13

Ibnu Hajar berkata,

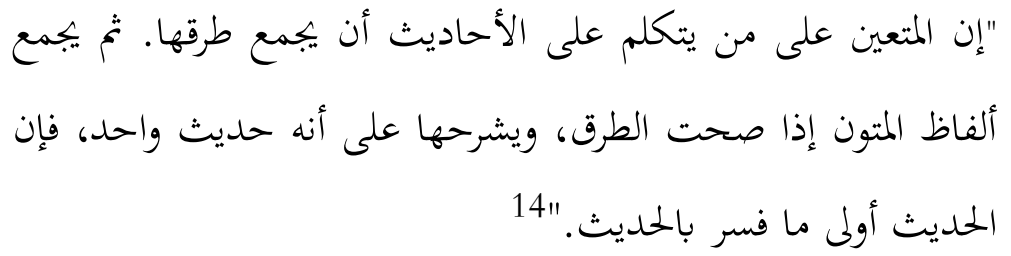

"Wajib bagi seorang yang akan berbicara mengenai hadis agar mengumpulkan jalur-jalur periwayatannya. Mengumpulkan lafal-lafal matan (dari jalur-jalur tersebut) jika jalurnya memang sahih. Dan dia menjelaskan hadis (syarb hadits)-dari jalur yang terkumpul tadi-seolah menjadi satu hadis. Karena hadis itu saling menafsirkan."

Ia juga berkata,

${ }^{12}$ Bazmul, Al-Mathali' Wa Al-Ushul Fiy Fahmi Ahadith Ar-Rasul, vol. 1/315.

${ }^{13}$ Bazmul, vols. 1/315-316.

14 Ahmad Ali Muhammad Ibnu Hajar, Fath Al-Bari Syrah Sabih Al-Bukhari (Beirut: dar al-Ma'rifah, 1379), vol. 6/475. 


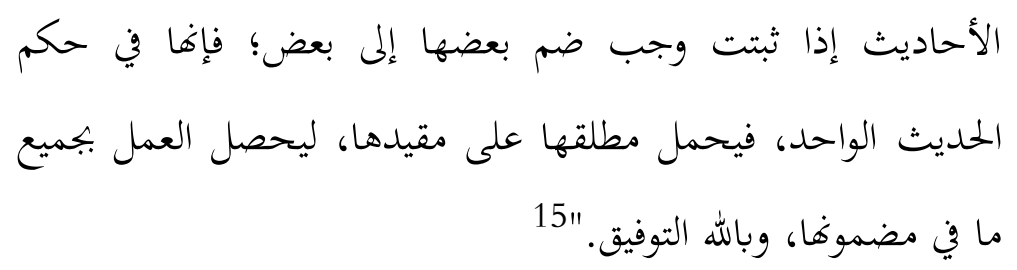

"Hadis, jika telah tsabit (sahih) wajib mengumpulkan semua riwayatnya. Seakan dia itu jadi satu hadis. Sehingga riwayat yang mujmal dibawa ke yang muqayyad, agar bisa beramal dengan semua kandungan hadis tersebut. Dan taufiq hanya dari Allah.”

Jika tidak memungkinkan untuk mendapatkan hadis yang menjelaskan hadis yang lainnya, maka beralih ke metode kedua. Syarh hadis dengan perkataan Sahabat, secara khusus rawi hadis, karena rawi hadis tentu lebih tahu dengan hadis yang diriwayatkannya. Terlebih Sahabat Nabi menelaah indikasi-indikasi keadaan di zaman turunnya wahyu dan pensyariatan, ditambah hati mereka lebih bertakwa kepada Allah dan lebih lurus dalam mengikuti sunnah. Sehingga pemahaman mereka terhadap hadis lebih dikedepankan dari pemahaman kita.

Oleh karena itulah, para ulama memiliki perhatian dengan atsar para Sahabat. Al-Auza'i (w. $157 \mathrm{H}$ ) sebagaimana dinukil oleh Bazmul berkata, "Ilmu itu yang Sahabat Muhammad datang dengannya, selain itu maka bukan ilmu." Dikisahkan bahwa alZuhri (w. $125 \mathrm{H}$ ) seorang tabii yang rajin menulis perkataan Sahabat, bersama dengan itu Saleh bin Kaisan menyelisihinya (tidak melakukan hal yang sama) maka Zuhri pun berhasil dan Saleh pun menyesal. Contoh kitab yang mengumpulkan atsar-atsar Sahabat dan Tabi'in seperti al-Muwaththa' karya Imam Malik, Mushannaf Abdurrazaq, dan Mushannaf Ibni Abi Syaibah. ${ }^{16}$

\footnotetext{
${ }^{15}$ Ibnu Hajar, vol. 11/270.

16 Bazmul, Al-Mathali' Wa Al-Ushul Fiy Fahmi Ahadith Ar-Rasul, vols. 1/318-319.
}

382 | TAJDID Vol. 20, No. 2, Juli - Desember 2021 
Jika tidak memungkinkan untuk mendapatkan atsar Sahabat dan mengumpulkannya dalam satu bab untuk memahami hadis, maka beralih ke metode berikutnya. Syarah hadis dengan perkataan Tabi'in, karena mereka memilki kekhususan yang tidak didapatkan oleh selain mereka. Zaman mereka lebih dekat ke zaman tasyri' (zaman Nabi), mereka merupakan murid-muridnya para Sahabat. Abl al-hadits juga perhatian terhadap atsar Tabi'in seperti halnya perhatian mereka terhadap atsar Sahabat, mereka menggabungkan nukilan dari kedua generasi ini di dalam satu tempat. ${ }^{17}$

Jika tidak memungkinkan untuk mendapatkan atsar Tabiin dan mengumpulkannya dalam satu bab untuk memahami hadis, maka beralih ke metode berikutnya. Syarah hadis dengan ijtihad dan studi bahasa, berpatokan pada perkataan para ulama yang biasanya terdapat di dalam kitab syuruh al-hadits atau merujuk ke kitab-kitab yang berhubungan dengannya dari kitab-kitab fikih, adab maupun akidah. ${ }^{18}$

Ibnu Abi al-Izz al-Hanafiy berkata, "Siapa pun yang mengira jika dirinya mengetahui hukum-hukum dari kitab dan sunah tanpa mengetahui perkataan para imam dan semisalnya maka dia telah salah besar. Walaupun kebenaran tidak mutlak berada pada perseorangan dari mereka, dan kesalahan tidak mutlak terjadi pada yang lainnya, hingga wajib mengikuti salah satunya tanpa yang lainnya. ${ }^{19}$

Syekh Muhammad Umar Bazmul berkata, "Inilah metode syarb al-hadits dan bayan ma'anibi. Meremehkan urutan di atas menyebabkan pemahaman yang buruk terhadap sabda Nabi dan keluar dari jalannya salaf al-ummah. Lalu ia menukil perkataan Ibnu Rajab, 'Sebaik-baiknya ilmu di dalam menafsirkan al-Qur'an, ma'ani al-hadits dan perkara halal dan haram adalah dengan nukilan yang

\footnotetext{
17 Bazmul, vols. 319-320.

${ }^{18}$ Bazmul, vol. 320.

19 Muhammad 'Ala Ibn Abi al-'Izz, Al-Ittiba' (Lebanon: 'Alam al-Kutub, 1405), 43.
} 
berasal dari Sahabat, Tabiin, dan pengikut mereka sampai zaman para imam Islam masyhur yang diteladani...."20

Kemudian produk jadi dari syarah hadis dengan tahapan di atas banyak tersebar. Seiring berjalannya waktu, syarah-syarah hadis pun mengalami kemajuan, dengan munculnya berbagai kitabkitab syarah hadis yang ditulis para ulama, begitu pun dengan sosial kemasyarakatan yang berkembang, menuntut ulama-ulama berinovasi agar setiap orang dapat dengan mudah memahami hadis dengan baik. ${ }^{21}$ Di dalam kitab syarah hadis, metode ulama-ulama dalam memaparkan syarah suatu hadis beragam, di antaranya ijmali (global), tablili (analitis), muqaran (komparasi) dan maudbu'i (tematik). ${ }^{22}$

\section{Hermeneutika dan Cendekiawan Islam Kontemporer}

Menurut Edi Susanto, istilah hermeneutika biasa dipahami sebagai "Seni dan ilmu menginterpretasikan teks terutama tulisantulisan bernilai tinggi; terutama dalam aplikasi untuk kitab suci dan setara dengan tafsir." Ada juga mendefinisikannya sebagai suatu filsafat yang memusatkan bidang kajiannya pada personal "understanding of understanding" (pemahaman pada pemahaman) terhadap teks, terutama teks kitab suci, yang datang dari tempat, waktu serta situasi sosial yang asing bagi para pembacanya. ${ }^{23}$ Adapun hermeneutika dalam kajian Alkitab Kristen didefinisikan sebagai suatu upaya berteologi dengan melibatkan hukum tertentu dan cara tertentu oleh seorang penafsir, dengan maksud atau

20 Bazmul, Al-Mathali' Wa Al-Ushul Fiy Fabmi Abadith Ar-Rasul, vols. 1/320-321.

21 Reza Pahlevi Dalimunthe and Nadea Siti, "Kontektualisasi Hadis : Menyikapi Penomena Prank Di Media Sosial," Diroyah Jurnal Studi Islam 5, no. 2 (2021): 139, https://doi.org/https://doi.org/10.15575/diroyah.v5i2.11212.

22 Alfatih Suryadilaga, Metodologi Syarah Hadis Dari Klasik Hingga Kontemporer (Sleman: Kalimedia, 2017), 11-12.

${ }^{23}$ Dr. Edi Susanto, Studi Hermeneutika Kajian Pengantar, 2. 
harapan menemukan maksud mula-mula dari para penulis aslinya Alkitab. ${ }^{24}$

Sebelumnya, perlu diketahui bahwa pola kerja hermeneutika adalah kajian mengenai hubungan dari tiga unsur utama hermeneutika yaitu pencetus (sumber), teks, dan pemirsa (penafsir). Hubungan yang terbentuk dari ketiganya menghasilkan adanya tiga hubungan: (1) hubungan pencetus dengan teks; (2) hubungan pemirsa dengan teks dan; (3) hubungan pemirsa dengan penggagas. ${ }^{25}$ Hubungan inilah yang nantinya akan diulas ketika prakteknya terhadap suatu teks tertentu.

Hermeneutika sebagai suatu pendekatan, demikian kata Edi Susanto, akhir-akhir ini banyak dibahas oleh para peneliti baik akademisi, sejarawan, kritikus sastra, antropolog, sosiolog, maupun cendekiawan Islam. Ketertarikan mereka ini lebih berfokus pada kajian memahami dan menafsirkan teks kitab suci, al-Qur'an dan Injil misalnya. ${ }^{26}$

Hermeneutika menjadi perbincangan hangat di kalangan cendekiawan dan ulama Islam jika diarahkan untuk menafsirkan alQur'an. Terlebih padanannya yaitu tafsir telah ada sejak awal Islam. Sehingga menafsirkan al-Qur'an dengan hermeneutika seakan menyimpang dari jalur yang benar. Meskipun begitu beberapa cendekiawan Islam menawarkan pendekatan hermeneutika dalam menafsirkan al-Qur'an. Sebut saja Fazlur Rahman, Muhammed Arkoun, Hassan Hanafi, Farid Esack, Muhammad Shahrur, Nasr Hamed Abu Zayd dan Khaled M. Abu El-Fadl adalalah di antara cendekiawan yang mempromosikan pendekatan hermeneutika dalam memahami agama.

Hasan Hanafi menyatakan bahwa hermeneutika itu bukan hanya teori pemahaman atau ilmu interpretasi tetapi juga berarti

${ }^{24}$ V Sitanggang, Menemukan Pesan Ilabi Prinsip-Prinsip Pendekatan Hermeneutik (Sukabumi: CV Jejak (Jejak Publisher), 2020), 8-10.

${ }^{25}$ Dr. Edi Susanto, Studi Hermeneutika Kajian Pengantar, 26.

${ }^{26}$ Dr. Edi Susanto, 3. 
ilmu yang menjelaskan penerimaan wahyu sejak dari tingkat perkataan sampai tingkat dunia, dari pikiran Tuhan kepada kehidupan Manusia. ${ }^{27}$ Dalam menafsirkan al-Qur'an, beberapa cendekiawan di atas menawarkan pendekatan hermeneutika tersendiri maupun hasil kombinasi dari teori Barat yang semuanya kebanyakan meruncing pada pendekatan sosiologis, antropologis, filosofis dan historis. Namun tentu saja hal ini mendapat respon pro dan kontra dari kalangan yang disebut tradisional, terlebih jika kesimpulan yang dihasilkan bertentangan dengan norma agama yang sudah ada.

Oleh karenanya, ketika membicarakan mengenai hermeneutika hadis, penulis berpikir bahwa hal yang sama juga akan terjadi. Terlebih para penggagas ide hermeneutika hadis mayoritas memakai pendekatan yang sama dengan yang diterapkan pada al-Qur'an. Sehingga penulis rasa memulai dari pembahasan pendekatan maupun teori hermeneutika hadis dirasa perlu sebelum melakukan perbandingan antara syarah hadis dan hermeneutika dalam menginterpretasi makna hadis.

\section{Hermeneutika Hadis}

Tiga unsur utama hermeneutika, pencetus (sumber), teks, dan pemirsa (penafsir) jika diterapkan pada hadis maka Rasulullah sebagai pencetus, matan hadis sebagai teks dan pemirsa sebagai pembaca/pensyarah/penafsir.

Hermeneutika sebagai pendekatan dalam menafsirkan teks termasuk hadis, tidak bisa berdiri sendiri, namun membutuhkan seperangkat pendekatan atau metode lainnya sebagaimana disebutkan bahwa metode yang digagas oleh cendekiawan Islam dalam menafsirkan al-Qur'an tidak terlepas dari pendekatan seperti ini. Contohnya Muhammad Arkoun yang menggunakan tiga pendekatan historis-sosiologis-antropologis dengan pendekatan

${ }^{27}$ Dr. Edi Susanto, 13.

386 | TAJDID vol. 20, No. 2, Juli - Desember 2021 
filosofis dan historis sebagai pelengkapnya. ${ }^{28}$ Begitu juga dalam menafsirkan hadis juga membutuhkan pendekatan semacam fenomenologi, sematik, linguistik, filologi dan lainnya.

Musahadi mengenalkan enam prinsip hermeneutika hadis, yaitu pertama, prinsip konfirmatif (menghubungkan antara makna hadis dengan al-Qur'an). Kedua, prinsip tematis komprehensif, (melihat hadis-hadis setema agar makna yang dihasilkan lebih komprehensif). Ketiga, prinsip linguistik (memperhitungkan gramatikal bahasa Arab, karena hadis Nabi dalam bahasa Arab). Keempat, prinsip historik (kajian sejarah fenomena-sosiolagi ketika hadis muncul dan asbab wurud-nya). Kelima, prinsip realistik (melihat kajian kekinian agar hadis dapat dimaknai sesuai zaman kini). Dan keenam, prinsip distingsi etis dan legis (menangkap nilai-nilai etis dari nilai legis yang hendak diwujudkan oleh sebuah teks hadis, karena pada dasarnya hadis-hadis Nabi saw. nilai-nilai etis yang lebih dalam bukan sekadar berisi hukum-hukum saja. ${ }^{29}$

Kemudian N. Kholis Hauqola mengatakan bahwa hermeneutika dalam kaitannya dengan penafsiran hadis memiliki tiga domain penafsiran. Pertama, penafsiran "dari dalam teks" yang merupakan cerminan dari hermeneutika teoritis atau hermeneutika romantis. Adapun langkah-langkahnya adalah (a) rekontruksi historis-objektif atau analisa teks secara bahasa (pendekatan linguistik); (b) rekonstruksi historis-subjektif atau analisa psikologi pencetus (sumber) sehingga teks bisa tetap hidup jika alasan dibalik tercetusnya ia dikesampingkan. ${ }^{30}$

${ }^{28}$ Dr. Edi Susanto, 79.

${ }^{29}$ Farah Nuril Izza, "Hermeneutika: Arah Baru Interpretasi Hadis (Studi Analisis Pemikiran Yusuf Al-Qardhawi Dalam Fatwa-Fatwanya)," KOMUNIKA: Jurnal Dakwah Dan Komunikasi 8, no. 2 (2014): 197, https://doi.org/https://doi.org/10.24090/komunika.v8i2.756.

${ }^{30}$ Nur Kholis Hauqola, "HERMENEUTIKA HADIS : Upaya Memecah Kebekuan Teks," TEOLOGLA 24, no. 1 (2013): 263-65, https://doi.org/https://doi.org/10.21580/teo.2013.24.1.324. 
Walaupun N. Kholis mengatakan bahwa pendekatan kritik matan hadis bisa digunakan dalam langkah pendekatan linguistik, namun kritik matan hadis menurut ahli hadis sejatinya bukanlah sekedar kritik matan secara bahasa (linguistik) tapi lebih kepada hasil interaksi hadis terhadap teks lainnya yang setingkat maupun logika dan fakta. Solah al-Din al-Adlabi menyebutkan bahwa dasardasar acuan dalam kritik matan ada empat yaitu tidak bertentangan dengan petunjuk al-Qur'an, tidak menyelisihi hadis yang sama derajatnya atau lebih, tidak menyelisihi akal sehat, indera, dan sejarah dan susunan pernyataannya menunjukkan ciri-ciri sabda kenabian. ${ }^{31}$ Adapun tinjauan secara bahasa maka lebih pas dikaitkan kepada gharib al-hadits dan ilmu bahasa Arab.

Kedua, penafsiran terhadap "hal-hal di sekitar teks" dengan kata lain psikologi pembaca/penafsir yang menjadi objek yang dikaji dalam penafsiran ini. Adanya indikasi subjektif dari penafsir meminta munculnya pembacaan ulang atau penafsiran ulang sehingga diperoleh penafsiran yang objektif bahkan lebih jauh lagi teks yang dibiarkan berbicara sendiri? Namun, hal ini tentu mustahil sebagaimana perkataan Hans-Georg Gadamer yang menilai tidak mungkin memperoleh pemahaman yang bersifat objektif dari sebuah teks. Ia juga mengatakan bahwa hermeneutik berhubungan dengan watak interpretasi, bukan teori interpretasi, karena makna lebih menyimpan nilai bagi kehidupan pembaca/penafsir, bukan bagi kehidupan penggagas. ${ }^{32}$

Domain kedua ini (penafsiran terhadap "hal-hal di sekitar teks") tidak berhubungan dengan rijal al-badits secara umum meskipun ada beberapa rawi yang menyampaikan hadis karena latar belakang tertentu namun kebanyakan mereka mendengarkan dan menyampaikan hadis di majlis tabdits, tentu generalisasi seperti ini tidak dibenarkan.

31 Abustani Ilyas La Ode Ismail Ahmad, STUDI HADIS: Ontologi, Epistemologi, Dan Aksiologi (Depok: PT. Raja Grafindo Persana, 2019), 125.

32 Hauqola, "HERMENEUTIKA HADIS: Upaya Memecah Kebekuan Teks," 266-67. 
Adapun mukharrij al-hadits maka mereka menyebutkan hadis yang sesuai dengan judul kitab dan bab yang mereka tetapkan, maka tindakan mereka ini memang termasuk dari hal-hal di sekitar teks dan ini tidak dipungkiri. Karena satu hadis bisa memiliki banyak interpretasi tidak hanya satu. Terlebih Nabi disifati dengan jawami' al-kalim.

Contohnya Bukhari yang terkenal dengan fiqh al-haditsnya menyebutkan hadis Abu Qatadah mengenai mimpi di tiga tempat dalam kitab sahihnya.

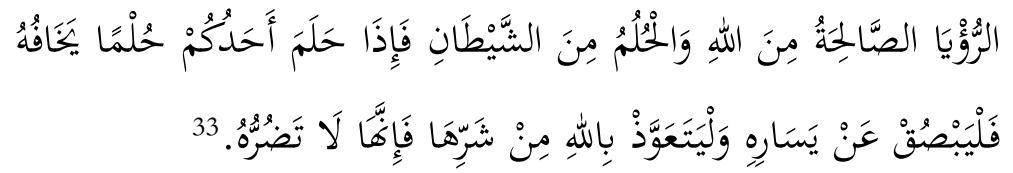

a. Kitab Bad'u al-Khalq, Bab Sifat Iblis wa Junudubu hadis nomor 3292.

b. Kitab al-Ta'bir, Bab al-Ru'yah al-Salibah Juz min Sittah wa Arba'in Juz'an min al-Nubuwab hadis nomor 6986.

c. Kitab al-Ta'bir, Bab Man Ra'a al-Nabi fi al-Manam hadis nomor 6995.

Ketiga, penafsiran "melawan" teks yang mana dalam prakteknya mengedepankan pendekatan sejarah. Karena sebuah penafsiran hadis diciptakan melalui interaksi sosial tempat terbentuknya teks dari Nabi yang kemudian diteruskan oleh para rijal al-hadits dan para pensyarah hadis yang semuanya saling berinteraksi dan membentuk kekuatan dalam struktur sosial yang diinginkan. Oleh karenanya pemaknaan harus dipusatkan pada bagaimana teks terbentuk dan dibentuk dari relasi sosial dan konteks sosial tertentu, sejak zaman Rasul hingga masa pensyarahan.

${ }^{33}$ Muhammad Isma'il al-Bukhari, Al-Jami' Al-Musnad as-Sabih Al-Mukhtasar Min Umur Rasulillab Shallahu 'alaibi Wa Sallam (Sabih Al-Bukbari) (Dar Turuq anNajah, 1422), 4/125, 9/30, 9/33. 
Intinya, hadis tidak hanya dilihat sebagai susunan teks belaka, namun berusaha digali kandungan makna literalnya dari konteks budaya maupun tafsir transendensi. Hermeneutika mencoba mengurai makna dengan mempertimbangkan sisi-sisi yang mengitari suatu teks hadis, yaitu sisi kebahasaan teks (linguistik dan sosial), pembaca (mukharrij dan mufassir) dan pencetus (posisi Nabi ketika bersabda) yang dengannya diharapkan dapat melacak sebab teks diutarakan oleh Rasul, muatan apa yang melingkupinya atau dimasukkan ke dalam cakupannya, sekaligus berusaha melahirkan kembali makna yang sesuai dengan situasi dan kondisi saat hadis dibaca atau dipahami dari zaman ke zaman. Interpretasi kemudian menjadi kegiatan rekonstruksi dan reproduksi makna hadis secara kontekstual. $^{34}$

Salah satu cendekiawan Islam yang digemari pendekatan hermeneutikanya adalah Nashr Hamid Abu Zaid. Ia berpendapat bahwa teks-termasuk al-Qur'an dan hadis-keberadaannnya selalu dipengaruhi oleh realitas dan budaya yang mana dalam hal ini dikaitakan olehnya dengan bahasa. Bahasa menjadi perantara antara pencetus dan pembaca/penerima sehingga dalam memahaminya harus memperhatikan realitas dan budaya di mana teks itu turun.

Hermeneutika Nashr Hamid Abu Zaid berfokus pada tiga pilar yang harus dijelaskan oleh penafsir, makna (dalalab), signifikasi (magza), dan maskut 'anbu (hal yang didiamkan tidak terkatakan). Dalam prosesnya, penafsir memosisikan dirinya pada kenyataan sekarang kemudian ia melihat intelektual masa lalu melalui ruang historis teks untuk mencari 'makna asal'. Setelahnya penafsir kembali ke masa kini untuk merekonstruksi ulang pesan teks 'signifikasi' barulah penafsir bisa membuka pilar 'maskut 'anbu' dari

${ }^{34}$ Hauqola, "HERMENEUTIKA HADIS : Upaya Memecah Kebekuan Teks," 170-73. 
pesan teksnya. ${ }^{35}$ Sehingga dalalab itu makna teks sesuai historisnya ketika disabdakan. Sedangkan signifikasi itu pemaknaan kembali ke konteks masa kini.

Namun yang perlu menjadi catatan adalah hermeneutika menganggap tidak adanya konsep kebenaran tunggal dalam penafsiran, yang ada hanyalah relativisme penafsiran sesuai tujuan dan maksud penafsir, serta meniscayakan berubah sesuai konteks yang berkembang. Bagi hermeneutika, semua orang adalah penafsir dengan latar belakang apapun ia, mengingat visi sang penafsir dalam memahami teks adalah untuk menjembatani masa lalu dan masa sekarang untuk kepentingan hidupnya.

Sebenarnya pendekatan ataupun metode hermeneutika para cendekiawan Islam yang telah disebutkan di muka bisa diaplikasikan ke dalam interpretasi hadis. Penulis tidak menyebutkan semuanya karena terkesan mengulang apa yang sudah banyak ditulis di dalam buku-buku dan artikel-artikel lainnya. Penulis melihat langsung ke pembahasan contoh interpretasi lebih menyampaikan maksud dari pada tujuan kajian ini.

\section{Contoh Interpretasi Hadis}

Penulis akan menyajikan contoh interpretasi antara hermeneutika dan syarah al-Hadis. Adapun hadis yang akan dikaji adalah hadis perintah memerangi manusia sampai mereka mengucapkan tiada Tuhan selain Allah.

Lafaz hadisnya adalah

35 Mohamad Nuryansah, "Aplikasi Hermeneutika Nashr Hamid Abu Zaid Terhadap Hadits Nabi," Millatī 1, no. 2 (2016): 264-65, https://doi.org/10.18326/millati.v1i1.259-278. 


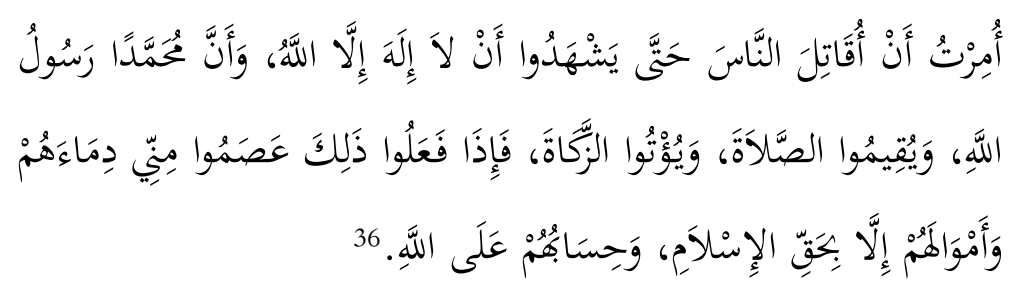

"Aku diperintah untuk memerangi manusia hingga mereka bersaksi tiada Tuhan selain Allah dan Muhammad Rasulullah, dan mendirikan salat, dan menunaikan zakat. Jika mereka melakukan hal itu maka terlindunglah darah dan harta mereka dariku kecuai dengan haq Islam, dan perhitungannya hanya kepada Allah.”

Hadis Ibnu Umar di atas adalah hadis muttafaq 'alaibi. Bukhari dan Muslim menyebutkannya dalam kedua sahihnya. Dan sebagaimana yang diketahui bahwa hadis muttafaq 'alaibi adalah derajat hadis sahih yang tertinggi. Sehingga tidak diragukan lagi akan keotentikan sanad dan matannya. Oleh karenanya pembaca ataupun penafsir bisa langsung fokus ke kajian pemahaman hadisnya.

\section{Syarah Hadis}

Ibnu Rajab (w. $795 \mathrm{H}$ ) dalam menjelaskan hadis ini, mengawalinya dengan menyebutkan semua riwayat yang berkaitan dengan perintah memerangi manusia sampai mengucapkan syabadatain. Karena riwayat hadis satu dengan hadis lainnya, meskipun se-tema keduanya saling menafsirkan.

Hadis di atas seakan mengandung makna bahwa Rasulullah diperintah (oleh Allah Ta'ala) agar memerangi manusia sampai mereka melakukan tiga hal, bersyahadat, salat, dan zakat. Namun setelah dikumpulkan semua riwayat yang se-tema Ibnu Rajab berkata,

36 al-Bukhari, Al-Jami' Al-Musnad as-Sahih Al-Mukhtasar Min Umur Rasulillah Shallabu 'alaibi Wa Sallam (Sabih Al-Bukbari), 1/14 hadis nomor 25.

392 | TAJDID vol. 20, No. 2, Juli - Desember 2021 


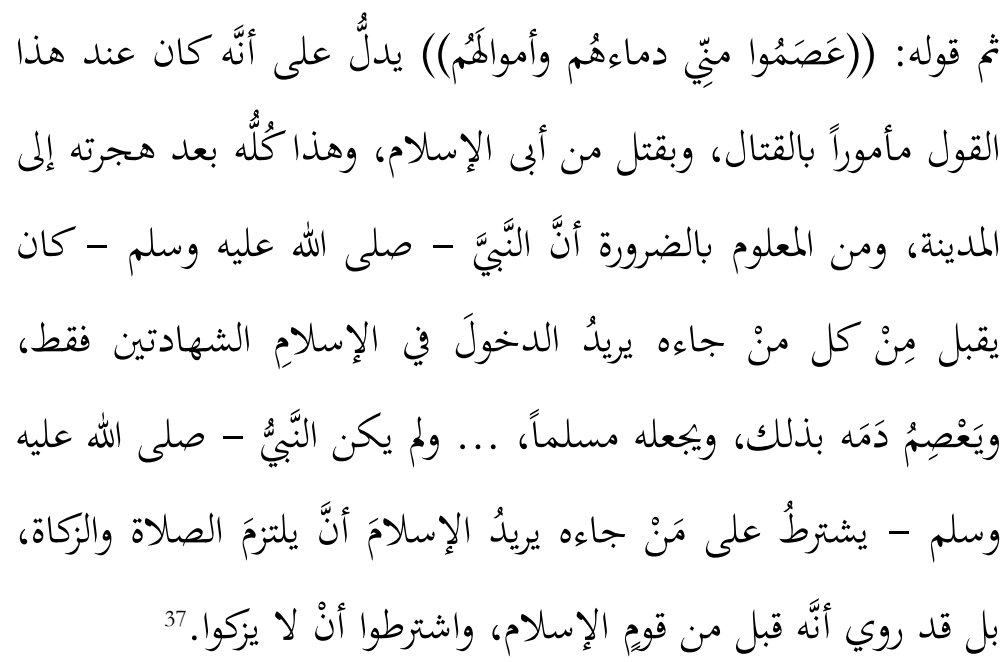

Perkataannya, "Terjaga dariku darahnya dan hartanya": menunjukkan bahwa Rasulullah ketika bersabda mengenai hadis ini, beliau sedang diperintah untuk perang, dan membunuh orang yang menolak masuk Islam. Tentu hal ini terjadi setelah hijrahnya ke Madinah. Dan termasuk perkara yang sudah maklum dalam agama ini bahwa Nabi saw. menerima Islam orang yang datang kepadanya dengan syahadatain saja dan darahnya terjaga karena itu dan menjadikannya muslim (dengan syahadatain saja)... dan Nabi tidak pernah mensyaratkan kepada orang yang datang kepadanya untuk masuk Islam bahwa dia harus salat dan zakat, bahkan terdapat riwayat bahwa Nabi menerima Islam dari suatu kaum yang bersyarat untuk tidak berzakat.

Alu Syekh dari ulama kontemporer mengatakan bahwa Allah memerintahkan untuk berperang hingga syariat dikerjakan, namun bukan berarti Nabi diperintahkan menyerang tanpa ada dakwah sebelumnya. Bahkan perintah ini dilaksanakan jika yang didakwahi tidak menyambut. Nabi tidaklah menyerang suatu kaum sampai datangnya dakwah Islam kepada mereka. Sudah diketahui dari sejarah bahwa Nabi mengirim surat-surat ke penjuru arah angin,

37 Abdurrahman Ahmad Ibn Rajab, Jami' Al-'Ulum Wa Al-Hikam Fi Syarb Khomsin Hadithan Min Jawami' Al-Kalim (dar al-Salam, 2004), 1/239. 
mengajak penduduknya masuk Islam atau akan diperangi jika tidak mau. Terlebih hadis ini diarahkan oleh para ulama kepada kaum musyrikin yang memang diberi pilihan anatara masuk Islam atau diperangi. Adapun ahlu kitab maka jika mereka menolak masuk Islam, mereka harus membayar jizyah, jika tidak maka akan diserang juga. ${ }^{38}$

Utsaimin mengatakan bahwa maksud dari sabda Nabi saw. "Kecuali dengan hak Islam" maksudnya adalah kecuali darah dan hartanya menjadi halal dengan sebab hak Islam yang dilanggar. Seperti zinanya orang yang sudah pernah menikah, atau ia terkena hadd qishah dan semisalnya yang mengakibatkan dia dihukum mati. Hadis ini adalah kaidah dan asas dalam permasalahan bolehnya menghabisi atau memerangi manusia jika melakukan sebab ini. ${ }^{39}$

Tidak lupa dalam syarah hadis para ulama biasanya menyebutkan faedah dari hadis. Di antara faedah yang bisa dipetik dari hadis ini adalah wajibnya memerangi manusia sampai mereka melaksanakan ibadah-ibadah yang disebutkan di hadis. Kenapa harus wajib dan bukan mustahab? Utsaimin berkata, ${ }^{40}$ "Tidak dihukumi dengan mustahab karena dalam membiarkan manusia dalam keadaan musyrik merupakan perkara yang haram. Dan membiarkan yang haram tidak terjadi kecuali dengan tujuan untuk medirikan yang wajib dengan memerangi yang haram tadi.

Hadis di atas juga mengandung banyak faedah yang di antaranya adalah tentang kewajiban jihad, terkadang fardhu kifayah dan terkadang fardhu 'ain. Dan tidak mungkin jihad dihukumi fardhu 'ain sama rata pada semua orang, karena Allah berfirman,

38 Saleh Abdul Aziz Alu Syaikh, Syarh Al-Arba'in an-Nawawiyah (Riyadh: Maktabah dar al-Hijaz, 1436), 143-44.

39 Muhammad Saleh al-Usaimin, Syarh Al-Arba'in an-Nawawiyah (dar alThuraya, n.d.), 128.

40 al-Usaimin, 128-29. 


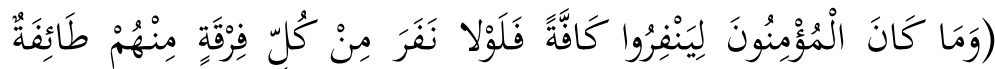

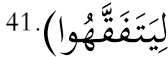

\section{Hermeneutika Hadis}

Pendekatan yang akan dipakai dalam menafsirkan hadis di atas adalah pendekatan hermeneutika Nashr Hamid Abu Zaid. Hadis di atas terdapat perintah memerangi (قاتل - وقاتل) qaatalayuqaatilu yang secara bahasa berarti memerangi. Berperang di sini maksudnya adalah jihad. Jihad mempunyai banyak makna, namun yang paling sesuai adalah seruan kepada agama yang haq. Ini karena kata jihad merujuk pada fi sabilillah (di jalan Allah) yang mana bisa dilakukan dengan banyak cara seperti melalui kontak fisik (perang), tangan atau lisan untuk mempertahankan agama Allah. Jihad, konsep yang multi makna, selalu problematik pada zaman sekarang, terlebih jika bersinggungan pada aplikatif. Sehingga memaknai kembali konsep jihad dengan kajian hermeneutika Nashr perlu untuk disajikan.

Dalam menemukan dalalah (makna) jihad, seorang mufasir harus memahami konteks sosio-kultural historis dari jihad itu sendiri. Pada masa awal Islam Nabi Muhammad menyebarkan Islam dibagi dalam dua periode yaitu periode Makkah dan periode Madinah. Ketika Nabi berdakwah di Makkah, belum ada perintah dengan redaksi jihad.

Nabi hanya berfokus untuk membentuk pribadi muslim secara utuh dan mengokohkannya untuk menghadapi gelombang tantangan yang dilancarkan kaum kafir Quraisy. Metode dakwah pada fase ini, berkerucut pada tiga hal. Pertama, mengarahkan risalah atau misi dakwah untuk meghadapi orang-orang kafir. Kedua, berusaha menampilkan eksistensi dakwah di hadapan musuh

\footnotetext{
${ }^{41}$ QS. 10:122.
} 
dengan cara lapang dada untuk memberi maaf dan menguatkan kesabaran. Ketiga, memberikan teladan yang baik.

Periode dakwah di Madinah perintah berjuang dengan redaksi jihad tegas digunakan. Pada periode ini, Rasulullah saw. terkadang mengambil jalan diplomasi atau berperang. Ada tiga jenis perang; pertama, qital difa'ay (perang bertujuan sebagai pertahanan dan membela diri); kedua, qital wiqa'aiy (perang pencegahan dengan melemahkan kekuatan musuh) dan; ketiga, qital ta'diby (perang sebagai bentuk pelajaran kepada pelanggar perjanjian).

Dengan demikian dalalah jihad adalah perang membela Islam dan mendakwahkannya. Sebaliknya, dakwah menyebarkan Islam adalah bagian dari jihad dalam pengertian yang lebih luas. Secara historis tradisi peperangan barulah disyariatkan ketika Islam sudah kuat dan perang menjadi keharusan yang tidak dapat dihindari, bahkan perang masih dilakukan sampai akhir perang dunia kedua.

Namun dalam konteks saat ini, di mana peradaban sudah berbeda jauh dan negara-negara dunia telah bersepakat dan berdamai. Maka memaknai hadis tersebut secara tekstual menjadi sebuah persoalan. Untuk itulah dipahami terlebih dahulu konsep jihad. Kalau menurut lafal hadis qaatala-yuqaatilu (memerangi) yang secara bahasa lebih bermakna tindakan yang berasal dari dua orang (ma'na musyarakah) begitu juga jihad merupakan bentuk isim masdar dari fi'il jaahada-yujaahidu yang memilki makna berjihad dengan penekanan dua orang. Artinya, jihad itu bukanlah disebut jihad jika hanya berasal dari satu pihak saja. Al-Utsaimin mengatakan muqatalah adalah usaha dalam berjihad memerangi musuh sampai kalimat Allah menjadi tinggi. ${ }^{42}$

Terlebih status manusia di zaman sekarang yang sudah tidak ada lagi kafir harbiy. Adapun secara teologis, jihad adalah pengerahan segala kemampuan dan potensi dalam memerangi

42 al-Usaimin, Syarh Al-Arba'in an-Nawawiyah, 1/126.

396 | TAJDID vol. 20, No. 2, Juli - Desember 2021 
musuh. Jihad adalah kewajiban bagi kaum muslim, bahkan ia penegak agama Allah.

Mohamad Nuryansah setelah menyebutkan konsep jihad dari beberapa tokoh Islam kontemporer berkesimpulan bahwa para pemikir Islam memberikan pengertian berbeda mengenai jihad, mulai dari aktivitas yang berhubungan dengan peperangan melawan musuh, melawan hawa nafsu, sampai pengertian sebagai usaha yang dilakukan secara serius untuk tujuan-tujuan yang baik. Kemudian ia berkata, "Nampaknya pengertian yang terakhir adalah yang paling cocok dan relevan dalam konteks saat ini." 43

Namun yang tepat bahwa semua konsep di atas masih relevan diterapkan. Adapun jihad dalam bentuk peperangan melawan musuh maka tidak relevan karena kondisi yang membawanya begitu. Semua negara di dunia ini sudah saling berdamai dan tidak ada saling serang. Namun itu bukan berarti jihad dengan perang sudah tidak relevan tapi tidak tepat diterapkan di masa kini.

Adapun maghza dari hadis tentang jihad di atas dapat dipahami bahwa jihad dengan cara kekerasan dan peperangan bukanlah cara jihad yang relevan untuk konteks sekarang ini. Umat Islam tentu tidak mau digambarkan sebagai pemeluk agama yang gemar peperangan dan kekerasan atau hal yang merugikan bagi Islam itu sendiri. Dari pendekatan hermeneutika di atas, dapat disimpulkan bahwa jihad dengan kekerasan dan peperangan hukumnya dilarang dalam konteks kekinian karena tidak adanya sebab yang syar'i.

\section{Penutup}

Berdasarkan uraian di atas bisa didapatkan bahwa syarah hadis dan pendekatan hermeneutika hadis bisa saling berjalan beriringan. Karena metode syarah hadis lebih mengedepankan

${ }^{43}$ Nuryansah, "Aplikasi Hermeneutika Nashr Hamid Abu Zaid Terhadap Hadits Nabi," 274-75. 
aspek hubungan antara pencetus dan pemirsa, ini bisa dilihat bahwa hadis diutamakan harus disyarah dengan hadis se-temanya, kemudian dengan tafsiran Sahabat, kemudian Tabiin yang notabene mereka dalam pengetahuan sejarah dan bahasa lebih mendalam dari orang setelahnya. Dibandingkan pendekatan hermeneutika yang berdasarkan asumsi budaya dan sosial yang lebih luas jangkauannya. Meskipun di satu sisi baik, namun tetap metode syarah hadis ulama lebih diutamakan dari pada pendekatan hermeneutika. Dalam menafsirkan hadis tidak hanya dibutuhkan pendekatan sejarah namun dibutuhkan interaksi antara adillah, alQuran dan sunnah. Prinsip yang diutarakan oleh Musahadi sepertinya harus dipahami dengan baik. Sehingga penafsiran yang tepat dapat dihasilkan. Saran bagi para peminat kajian hermeneutika hadis yang ingin menerapkan hadis untuk terlebih dahulu membaca kajian syarah ulama, terlebih di dalamnya terdapat penjelasan mengenai kaidah ataupun ijmak yang tidak boleh diganggu gugat. Terlebih jika hadis tersebut mencapai derajat mutawatir. Maka tidak ada tawar-menawar lagi.

\section{Daftar Pustaka}

Abustani Ilyas La Ode Ismail Ahmad. STUDI HADIS: Ontologi, Epistemologi, Dan Aksiologi. Depok: PT. Raja Grafindo Persana, 2019.

al-Bukhari, Muhammad Isma'il. Al-Jami' Al-Musnad as-Sabih AlMukbtasar Min Umur Rasulillah Shallabu 'alaibi Wa Sallam (Sabih Al-Bukhari). Dar Turuq an-Najah, 1422.

al-Usaimin, Muhammad Saleh. Syarb Al-Arba'in an-Nawawiyah. dar al-Thuraya, n.d.

Alu Syaikh, Saleh Abdul Aziz. Syarh Al-Arba'in an-Nawawiyah. Riyadh: Maktabah dar al-Hijaz, 1436.

ar-Razi, Muhammad Abi Bakr. Mukhtar As-Sihah. Beirut: ad Dar an Namudzajiyyah, 1999.

as-Sakhowi, Muhammad Abdurrahman. Fath Al-Mughith Bi Syarh Alfiyah Al-Hadith. Mesir: Maktabah as Sunnah, 2003.

398 | TAJDID vol. 20, No. 2, Juli - Desember 2021 
Bazmul, Muhammad Umar Salim. Al-Mathali' Wa Al-Ushul Fiy Fabmi Abadith Ar-Rasul. Jaza'ir: Dar al-Mirath an-Nabawiy, 2017.

Dalimunthe, Reza Pahlevi, and Nadea Siti. "Kontektualisasi Hadis : Menyikapi Penomena Prank Di Media Sosial.” Diroyah Jurnal Studi Islam 5, no. 2 (2021): 138-44. https://doi.org/https://doi.org/10.15575/diroyah.v5i2.112 12.

Dr. Edi Susanto, M F I. Studi Hermeneutika Kajian Pengantar. Jakarta: Kencana, 2016.

Fairuzabadi, Muhammad Ya'kub al. Al-Qamus Al-Mubith. Beirut: Muassasah ar-Risala, 2005.

Fawaid, Ahmad. "Reinterpretasi Hadis Tentang Mahram (Pendekatan Hermeneutika)." Nur El-Islam 3, no. 1 (2016): 176-95.

https://ejurnal.iaiyasnibungo.ac.id/index.php/nurelislam/ar ticle/view/38.

Hauqola, Nur Kholis. "HERMENEUTIKA HADIS: Upaya Memecah Kebekuan Teks." TEOLOGLA 24, no. 1 (2013): 261-84.

https://doi.org/https://doi.org/10.21580/teo.2013.24.1.32 4.

Ibn Abi al-'Izz, Muhammad 'Ala. Al-Ittiba'. Lebanon: 'Alam alKutub, 1405.

Ibn Manzhur, Muhammad Mukrim Ali. Lisan Al-'Arab. Beirut: dar al-Shodir, 1414.

Ibn Rajab, Abdurrahman Ahmad. Jami' Al-'Ulum Wa Al-Hikam Fi Syarb Khomsin Hadithan Min Jawami' Al-Kalim. dar al-Salam, 2004.

Ibnu Hajar, Ahmad Ali Muhammad. An-Nukat 'ala Kitab Ibn asSalah. Madinah: 'Imdah al-Bahth al-'ilmi bial-Jamiah alIslamiyah, 1984.

Ma'rifah, 1379.

TAJDID vol. 20, No. 2, Juli - Desember 2021 | 399 
Muhammad Syarifuddin dan Masruhan

Ibnu Hajar, Imam. "Reinterpretasi Hukum Larangan Bepergian Tanpa Mahram Bagi Perempuan.Pdf." Al-Manahij: Jurnal Kajian Hukum Islam 6, no. 1 (2012): 143-56. https://doi.org/https://doi.org/10.24090/mnh.v6il.594.

Izza, Farah Nuril. "Hermeneutika: Arah Baru Interpretasi Hadis (Studi Analisis Pemikiran Yusuf Al-Qardhawi Dalam FatwaFatwanya)." KOMUNIKA: Jumal Dakwah Dan Komunikasi 8, no. 2 (2014): 192-220. https://doi.org/https://doi.org/10.24090/komunika.v8i2.7 56.

Nuryansah, Mohamad. "Aplikasi Hermeneutika Nashr Hamid Abu Zaid Terhadap Hadits Nabi.” Millatī 1, no. 2 (2016): 259-78. https://doi.org/10.18326/millati.v1i1.259-278.

Siregar, M Nasrun, Ihsan. "REINTERPRETASI HADIS MAYAT DIAZAB ATAS TANGISAN KELUARGANYA." Ulul Albab 19, no. 1 (2018): 142-59. https://doi.org/10.18860/ua.v19i1.4837.

Sitanggang, V. Menemukan Pesan Ilabi Prinsip-Prinsip Pendekatan Hermeneutik. Sukabumi: CV Jejak (Jejak Publisher), 2020.

Suryadilaga, Alfatih. Metodologi Syarah Hadis Dari Klasik Hingga Kontemporer. Sleman: Kalimedia, 2017.

400 | TAJDID vol. 20, No. 2, Juli - Desember 2021 